Further research is clearly needed to investigate this inequality and provide aetiological clues.

1 Griffiths RK, Kyle DR, Cooper RF, et al. A picture of health? Annual report 1987. Birmingham: Central Birmingham Health Authority, Department of Community Medicine, 1987.

2 Gillies DRN, Lealman TL, Lumb KM, Congdon P. Analysis of ethnic influences on stillbirths and infant mortality in Bradford 1975-1981. J Epidemiol Community Health 1984;38:214-7.
Terry PB, Condie RG, Bissenden JG, Kerridge DF. Ethnic differences in incidence of very low birthweight and neonatal deaths among normally formed infants. Arch Dis Child 1987;62:709-11.

4 Black L, David G, Brouillette RT, Hunt CE. Effects of birthweight and ethnicity on incidence of sudden infant death syndrome. F Pediatr 1986;108: 209-10.

5 Hogue CJ, Buehler JW, Strauss LT, Smith JC. Overview of the national infant mortality surveillance (NIMS) project. Public Health Rep 1987;102:126-37.

(Accepted 8 June 1988; proof returned 15 December)

\section{Autoimmunity: a risk factor for allosensitisation to blood products?}

\author{
A S Wierzbicki, D M Cousins
}

\section{Department of}

Haematology, National

Hospitals for Nervous

Diseases, Queen Square,

London WC1N 3BG

A S Wierzbicki, BM, senior house officer

D M Cousins; BSC, senior

medical laboratory scientific officer

\section{Correspondence and} requests for reprints to: $\mathrm{Dr}$ Wierzbicki.

Br.Med f 1989;298:95-6 over 10 months.

\section{Case histories}

Transfusion of blood products sensitises some patients to isoantigens. We report three cases of the formation of multiple persistent isoantibodies that occurred in association with a complex of autoimmune diseases

Case 1-A 50 year old woman with a history of rheumatoid arthritis treated with various agents including prednisolone was admitted for odontoid peg surgery. She had had two pregnancies, and six years before admission she had received 5 units of packed erythrocytes during three orthopaedic operations. Clinically she had vitiligo and hypothyroidism. Initially only anti-rhesus E and anti-Duffy antibodies were detected. Postoperative transfusion was followed by a delayed haemolytic transfusion reaction at 10 days. Further surgery for a cerebrospinal fluid leak required repeat transfusion, which disclosed additional antiKell, anti-rhesus C, anti-Kidd, and HLA antibodies to $80 \%$ of a lymphocyte panel (North West Thames Regional Blood. Transfusion Centre, Edgware). Further episodes of haemolysis occurred until fully crossmatched blood (also anti-S negative) was used. She was managed symptomatically and made a good recovery.

Case 2-A 65 year old nullipara presented with a right frontal glioma and a history of aplastic anaemia managed by splenectomy (eight years). She had been treated with prednisolone five years previously. Her total transfusion history was 8 units of packed cells up to six years previously and 12 units of platelets up to nine years previously. Her autoimmunity was manifested by vitiligo, hypothyroidism, and pernicious anaemia. On admission she was anaemic $(105 \mathrm{~g} / \mathrm{l})$ and thrombocytopenic $\left(26 \times 10^{9} / 1\right)$ and was crossmatched for red cell transfusion. Repeat crossmatching two hours after platelet transfusion, when she remained thrombocytopenic, disclosed HLA antibodies. This necessitated tissue typing before revision of her bone flap. During the transfusions she had a mild trans- fusion reaction on four occasions. Eventually she recovered.

Case 3-A 51 year old woman was admitted for thymectomy after presenting with myasthenia gravis. She had a previous history of hypothyroidism and breast adenocarcinoma and was receiving long term prednisolone. She had borne three children. Her total transfusion history was 4 units of packed cells two years previously. Her thymectomy was uneventful and she did not require transfusion. She made a good recovery.

The table gives details of the antibody profiles in the three cases.

\section{Comment}

Blood product isoantibodies and autoantibodies are becoming commoner with the frequency of multiple transfusions and bone marrow transplant operations. The prevalence of isoantibodies varies from $0.5 \%$ to $3.8 \%^{1}$ or a reaction occurs to roughly one in 4000 units of blood transfused. ${ }^{2}$ Usually, however, antibodies are to only one blood group-for example, rhesus-and they occur in $10-36 \%$ of multitransfused patients. ${ }^{34}$ Rarely two blood groups are affected $(10 \%$ of delayed transfusion reactions), but three or more are very rare (1\%). Most of these antibodies decline in titre over four years to $60-80 \%$ of their original prevalence. ${ }^{5}$ AntiKidd and anti-rhesus $\mathrm{E}$ are commonly seen in allosensitisation and also reappear on restimulation, as occasionally does anti-Duffy. ${ }^{4}$

Our patients were unusual in that their exposure to blood products was small and had occurred several years previously. Multitransfusion studies cite transfusions of 10-20 units one year previously. ${ }^{3}$ The three patients were immunosuppressed with steroids, which should have reduced their predisposition to allosensitisation.

All three patients were of the sex and age groups particularly affected by autoimmune diseases, and all showed pronounced immune dysfunction manifested by formation of multiple autoantibodies. We suggest that this defect in their immune suppressor mechanisms might also have predisposed them to the induction and persistence of antibodies against blood products. This type of patient might therefore benefit from more accurate crossmatching for minor blood groups to avoid the possibility of later delayed haemolytic transfusion reactions.

ADDENDUM - Since submitting this report we have seen a further case of a 59 year old nullipara with

Results of blood crossmatching and screening for autoantibodies and isoantibodies in three patients

\begin{tabular}{|c|c|c|c|}
\hline & Case 1 & Case 2 & Case 3 \\
\hline Erythrocyte crossmatch & Normal & Normal & Normal \\
\hline Direct antiglobulin test result & Negative & Negative & Negative \\
\hline Autoantibodies (titre) & $\begin{array}{l}\text { Thyroglobulin }(1 / 640) \text {; thyroid } \\
\text { microsome }(1 / 320) \text {; antinuclear } \\
(1 / 80) \text {; rheumatoid antinuclear } \\
(1 / 64)\end{array}$ & $\begin{array}{l}\text { Thyroglobulin }(1 / 320) \text {; thyroid } \\
\text { microsome }(1 / 160) \text {; intrinsic } \\
\text { factor; parietal cell }\end{array}$ & $\begin{array}{l}\text { Thyroglobulin (1/640); thyroid } \\
\text { microsome (1/640); antinuclear } \\
\text { (1/320); striated muscle; } \\
\text { acetylcholine receptor }\end{array}$ \\
\hline Isoantibodies & $\begin{array}{l}\text { Rhesus C, E; Duffy; Kell; Kidd; } \\
\text { HLA }(80 \%)\end{array}$ & HLA $(90 \%)$ & Rhesus C, D; Kidd \\
\hline
\end{tabular}


rheumatoid arthritis and isoantibodies to rhesus (C, D) and Duffy blood groups.

1 Decary F, Fermer P, Giaredoni L, et al. An investigation of nonhaemolytic transfusion reactions. Vox Sang 1984;46:277-85.

Moore SB, Taswell HF, Pineda AA, Sonnenberg CL. Delayed hemolytic transfusion reactions. Am f Clin Pathol 1980;74:94-7.
3 Lasky LC, Rose RR, Polesky HF. Incidence of antibody formation and positive direct antiglobulin tests in a multitransfused hemodialysis population. Transfusion 1984;24: 198-200.

Mollison PL, Engelfriet CP, Contreras M. Blood transfusion in clinical medicine. 8th ed. Oxford: Blackwell, 1987:617-36, 689-722.

5 Ramsay G, Larson P. Loss of red cell alloantibodies over time. Transfusion $1988 ; 28: 162-5$

(Accepted 29 September 1988)

\title{
Treatment of itching in atopic eczema with antihistamines with a low sedative profile
}

\author{
V Doherty, D G H Sylvester, C T C Kennedy, \\ S G Harvey, J G Calthrop, J R Gibson
}

Department of

Dermatology, Western

Infirmary, Glasgow

V Doherty, MRCP, registrar

\section{Department of}

Dermatology, Bristol Royal

Infirmary, Bristol

D G H Sylvester, MRCGP,

honorary clinical assistant

C T C Kennedy, FRCP,

consultant dermatologist

\section{Section of Dermatology,}

Wellcome Research

Laboratories, Beckenham, Kent BR3 3BS

S G Harvey, BSC; clinical

research associate

research associate

J R Gibson, FRCPGLAS, head

Correspondence to:

Dr Gibson.

BrMed f 1989;298:96
J G Calthrop, BSC, clinical

The mechanisms of itching associated with atopic eczema remain controversial. Treatment with conventional antihistamines is generally thought to benefit the patient only by a central mechanism concerning sedation,' though there are scant clinical data to support this contention. The availability of a new generation of antihistamines with a low sedative profile, such as terfenadine ${ }^{2}$ and acrivastine ${ }^{34}$ has yielded the chance to explore further the mechanisms of itching in atopic eczema and to evaluate whether such agents are likely to yield benefits additional to those of treatment with topical corticosteroids and emollients.

\section{Patients, methods, and results}

Forty nine adult outpatients with a clinical diagnosis of atopic eczema ( 20 men, 29 women; mean age 26.8 (range 16-58) years) were entered into the study with their informed consent. The study's design was parallel, fully randomised, double blind, and placebo controlled. The treatment courses of 10 days consisted of three doses a day of acrivastine $8 \mathrm{mg}$, terfenadine $60 \mathrm{mg}$, or placebo. All patients were concomitantly treated with a standardised regimen of topical treatment consisting of a twice daily application of $0.05 \%$ clobetasone butyrate ointment and aqueous cream as a soap substitute.

Patients were evaluated on entry into the study and after seven and 14 days. Techniques of assessment

Summary of patients' self assessment and investigators' dato

\begin{tabular}{lccc}
\hline & $\begin{array}{c}\text { Placebo } \\
(\mathrm{P})\end{array}$ & $\begin{array}{c}\text { Acrivastine } \\
(\mathrm{A})\end{array}$ & $\begin{array}{c}\text { Terfenadine } \\
(\mathrm{T})\end{array}$ \\
\hline & Patient's self assessment & & \\
No of patients for whom data available & 14 & 13 & 16 \\
No in whom treatment helped condition & 4 & 9 & 11 \\
p Value for comparison (Fisher's exact test) & $\mathrm{P} v \mathrm{~A}, 0.057$ & $\mathrm{~A} v \mathrm{~T}, \mathrm{NS}$ & $\mathrm{P} v \mathrm{~T}, 0.066$
\end{tabular}

Visual analogue scale

No of patients for whom data available Mean score

Difference in mean scores

$95 \%$ Confidence interval for difference

p Value for comparison (Newman-Keuls multiple range test)

12
$46 \cdot 4$
$\mathrm{P} v \mathrm{~A}, 11 \cdot 4$
$-1 \cdot 7$ to $24 \cdot 5$
$0 \cdot 08$

11

$35 \cdot 0$
$\mathrm{~A} v \mathrm{~T}, 3 \cdot 8$

15
$31 \cdot 2$

P $v \mathrm{~T}, 15 \cdot 2$

$\begin{array}{lc}0.55 & 3 \cdot 1 \text { to } 27 \cdot 3 \\ & 0.01\end{array}$

\section{Degree of benefit}

No of patients for whom data available Mean score

Difference in mean score

$95 \%$ Confidence interval for difference

p Value for comparison (Mann-Whitney U test)
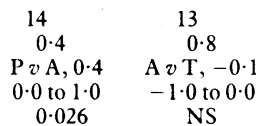

$$
\begin{gathered}
16 \\
0.9 \\
\mathrm{P} v \mathrm{~T}, 0.5 \\
0.0 \text { to } 1.0 \\
0.037
\end{gathered}
$$

\section{Investigators' assessment}

No of patients for whom data available No in whom treatment helped itching

p Value for comparison (Fisher's exact test)

$\begin{array}{ccc}14 & 13 & 16 \\ 4 & 10 & 10 \\ \mathrm{P} v \mathrm{~A}, 0.021 & \mathrm{~A} v \mathrm{~T}, \mathrm{NS} & \mathrm{P} v \mathrm{~T}, 0.081\end{array}$

^Adjusted with baseline scores as a covariate; minimum $=0$, maximum $=100$.

† $0=$ No improvement, $3=$ completely relieved. included patients' self assessment forms, visual analogue scales completed by the patients (on entry and after seven days), and an investigator's assessment based on direct questioning and careful examination of the skin. Data relevant to the control of itching, overall benefit to the patient, adverse events, and the acceptability of and compliance with treatment were collected.

At the end of the study data from 44 patients (18 men, 26 women; mean age 26.6 (range 16-58) years) were available for analysis. Five patients (three taking acrivastine, one taking terfenadine, and one taking placebo) failed to return for follow up. The table summarises the results. The two active agents were more effective than placebo for all variables assessed. Acrivastine significantly reduced itching when compared with placebo according to the doctor's assessment $(p=0.021$, Fisher's exact test $)$. Both acrivastine $(p=0.026$, Mann-Whitney $U$ test $)$ and terfenadine $(p=0.037$, Mann-Whitney $U$ test $)$ improved the patient's condition significantly more than placebo according to the patient's assessment of the degree of benefit obtained. Terfenadine significantly reduced itching on day 7 compared with placebo, according to the visual analogue scale $(\mathrm{p}=0.01$, Newman-Keuls multiple range test). Generally the data indicated that the benefit provided by the active agents was slight but clearly detectable. No significant differences were found between the two active treatments.

\section{Comment}

Our results suggest that acrivastine and terfenadine can partially relieve itching in atopic eczema. These data are perhaps more striking when it is considered that these antihistamines were effective against a background of concomitant treatment with a moderately potent corticosteroid ointment and an emollient soap substitute. This suggests that these agents can enhance the benefits of routine topical treatment for atopic eczema.

The ability of two separate agents, whose only known mechanism of action is through blockade of $\mathrm{H}_{1}$ histamine receptors and which are both devoid of any major sedative action, to alleviate itching in some patients with atopic eczema has interesting mechanistic implications. The data imply that histamine has an active role, though the mechanisms of itch may not be homogenous in nature and the part played by histamine may be greater or smaller in individual patients.

The widely held belief that treatment of itching in atopic eczema with older, traditional antihistamines operates only by the well known sedation associated with such agents must be questioned.

Krause $\mathrm{L}$, Shuster S. Mechanism of action of antipruritic drugs. Br Med $\mathcal{f}$ 1983;287:1199-200.

Sorkin EM, Heel RC. Terfenadine: a review of its pharmacodynamic properties and therapeutic efficacy. Drugs 1985;29:34-56.

3 Cohen AF, Hamilton M, Philipson R, Peck AW. The acute effects of acrivastine (BW 825C), a new antihistamine, compared with triprolidine on measures of central nervous system performance and subjective effects. Clin Pharmacol central nervous system

4 Juhlin L, Gibson JR, Harvey SG, Huson LW. Acrivastine versus clemastine in the treatment of chronic idiopathic urticaria: a double-blind, placebocontrolled study. Int f Dermatol 1987;26:653-4.

(Accepted 28 September 1988 